\title{
Implementation of Entrepreneurship Education \\ Programme in Tertiary Educational Institutions and \\ Graduate Employment in Nigeria: The Perspective of \\ Cross River State
}

\author{
Joseph Etiongbie Ogbiji, $\mathrm{PhD}$ \\ Department of Educational Foundations and administration, \\ Faculty Education, Cross River University of Technology, \\ Calabar, Nigeria
}

Received: May 22, 2018 Accepted: August 6, 2018 Online published: August 14, 2018

doi:10.5296/ijhrs.v8i3.13496 URL: https://doi.org/10.5296/ijhrs.v8i3.13496

\begin{abstract}
This research investigated the effects of the implementation of Entrepreneurship Education (ENT) programme among tertiary education institutions in Nigeria on graduates employment, with particular reference to Cross River State. Entrepreneurship Education programme was made mandatory for all tertiary educational institutions in Nigeria from 2007/2008 academic session as an antidote to the scourge of graduates unemployment in the country. Four research questions which investigated the extent of programme implementation, inculcation of love for entrepreneurship, graduates self-employment and general students perception of the programme were used to carry out the study. The study population compressed 26,000 graduates projected to have graduated from the four tertiary educational institutions in Cross River State within the ten years of the programme implementation. Using ex-post facto research design, a sample of 2,600 representing 10 percent of the population was studied, using 11-item researcher-made questionnaire titled "Entrepreneurship Education and Graduates Employment Questionnaire" Data analysis was done using simple percentages. The findings reveal that ENT is widely implemented (67.78\%) among tertiary educational institutions; the course is not well taught (61.94) among schools; that there were no industrial experience or visits by learners $(76.79 \%)$ but that the course has introduced learners to many trades (59.27) and that some beneficiaries of the course have becomes self-employed through the inspiration drawn from it $(9.93 \%)$. There is a consensus view that the course holds great
\end{abstract}


potentials for graduate employment $(90.90 \%)$. From the findings it was concluded that ENT has great prospects for graduates self-employment and accordingly recommended for improvement in programme implementation.

\section{Introduction}

Before the introduction of Western Education into Nigeria from 1842, there was nothing like unemployment among the different peoples of Nigeria. This was so because the traditional education system was comprehensive and provided for full employment of citizens (Fafunwa, 1995, Fajana, 2000). It was based on the seven cardinal objectives which Fafunwa (1995) identified to include: the development of the child's latent physical skills, develop character, inculcate respect, develop intellectual skills, vocational training and Patriotism (P.20).

Entrepreneurial mindset was prevalent among all ethnic groups that comprise present day Nigeria (Udo, 1983, Raimi,Shokunbi and Peluola 2010). The Hausa, the Yoruba, the Ibo, the Ibibio and other ethnic groups had traditional education curriculum that provided for the social, economic and political needs of the society and the upcoming generations in a manner that every adult was gainfully employed in the various occupations prevalent at the time.

With industrial revolution in Europe, came the colonization of Africa and other parts of the world as avenues or markets for raw materials and finished goods from Europe. With colonization, came the introduction of Christianity and western education. Western education was aimed at providing literacy that will enhance more active participation in Christian worship and provide man-power for employment in church service, commerce and colonial public service. Due to the limited resources for providing western education, only very few people could benefit from the education system. The few beneficiaries found ready employment in church service as clergy, and lay workers in the church. Others became employed as teachers, clerks in the public service and workers in commercial firms. This new lease of life for beneficiaries of western education became a lure for other Nigerian youth who were still engaged in the traditional back-braking farming industry. But as long as colonialism lasted (1860-1960) products of western education were in short supply in the labour market due to the limited educational opportunities at the time, and the expanding colonial administration, church industry and commercial activities into the hinterlands.

But with the attainment of political independence from Britain in 1960, government attention was now focused on social, economic, political and infrastructural development of the country. Primary, secondary and tertiary education were given a boost through the injection of the national resources into the provision of educational services across the country. Before independence Nigeria had no university, except a campus of Cambridge University, located at Ibadan since 1948. Prior to the attainment of independence in October, the Eastern Region of Nigeria opened the university of Nigeria at Nsukka in Sept. 1960. Within the first five years of Nigeria's independence the number of universities rose to five (Fafunwa 1995). By 1975 the number of universities had risen to thirteen. In the following year (1976) Universal Free Primary Education (UPE) was declared for Nigeria. This opened the floodgate for all children in the country to attend primary school at government expense. This was extended to junior secondary education in 1999. 
As at January 2017, Nigeria has a total of forty (40) Federal Government universities and thirty-eighty (38) state-owned universities. There are also scores of other privately-owned universities (Fed. Min. of Edu 2017, Nig.www.Ret 2010-03-17, US Diplomatic Mission to Nig. www $2010-03-17$ ). Nigeria also has a total of 103 polytechnics of which 40 are owned by the Federal Government, 41 by state governments and 22 by individuals and organizations. The country also has 82 Colleges of Education, of which 27 are owned by the Federal Government, 46 by state governments and 14 by individuals and organizations (Wikipedia, March, 2017). Colleges of Education produce National Diploma holders in education.

From the above data it is obvious that Nigeria has made a remarkable progress in the development and expansion of the education sector. It is also noteworthy that great awareness has been created in the area of education to the extent that majority of the youth aspire to be educated in view of its benefits which includes getting a salary or white collar job.

The speed with which the proliferation of educational institutions at all levels were pursued in Nigeria within the past fifty years smacks of the expected quality in a third world country characterized by inadequacies of funds, technology and infrastructure. Concomitantly, the country's educational institutions now produce graduates who are not employable in both the public and private sectors because they lack the basic skills required by industries as well as the basic entrepreneurial skills required for job creation and self-employment (Yahaya 2011).

These graduates have now become liabilities to themselves, their families and the nation. Until recently most of these graduates were produced with the hope that there were employment opportunities in the labours market for them. Now it has become obvious from both the public and the private sectors that there are no rooms to absorb all the graduates of tertiary educational institutions.

\section{The Need for Entrepreneurship Education}

Based on the realization of the flaws found in the implementation of the nation's education programme, which the Federal Government wants to use as an instrument for national development, Federal Republic of Nigeria, (2008), it became clear to government that there is need to include Entrepreneurship Education as a compulsory course in the national education curriculum. The course is expected to serve as an antidote to graduate unemployment as it will equip them with entrepreneurship skills of self-employment and also bridge the gap between the industries and products of tertiary educational institutions. Consequently, the Federal Republic of Nigeria mandated the Federal Ministry of Education to introduce Entrepreneurship Education into the nation's tertiary education curriculum and make it mandatory for all universities, polytechnics and colleges of Education from 2007/2008 academic session (Gbadeen and Raimi, 2012).

Conceptually Entrepreneurship Education (ENT) refers to a specialized knowledge that inculcates in the learners the ability and willingness of risk taking, innovation and coordination of factors of production for the purpose of creating new products or services for new and existing users (Acs and Storey, 2004, Nude, 2007; Minniti and Levesque, 2008; 
Kanothi, 2009). It is the process of providing individuals with the ability to recognize commercial opportunities and the knowledge, skills and aptitude to take advantage of the opportunities. As an education programme, entrepreneurship education is capable of developing in the learners the ability to identify business opportunities, generate programmatic ideas and evaluate the extent to which the window could be harnessed.

\section{Theoretical Framework}

The study was based on two theoretical framework. They are the Human Capital Development theory as in Robert (1991) and Need for Achievement Theory of McClelland (1965). Human Capital Development Theory emphasizes education as a tool for boosting human capital, stimulating labour productivity and accentuating the application of technology globally (Robert, 1991). It sees expenditure on education and training of human capital as productive investment just like investment on physical assets (Van-Dean-Berg 2001, Adegun, 2003, Olaniyan and Okemakinde, 2008). Vanden-Berg (2001) established a correlation between the level of education and new product development in knowledge-based economies that place priority on education and technological development.

In the same Vein, Adegun (2003), ventilating the classical economists view paint sees expenditure on human capital development as investment that yields many returns to the economy. This theory is supportive of introducing Entrepreneurship Education Programme into the nations education curriculum as it will produce skilled man-power that will enhance national development and mitigate graduate unemployment.

The need for Achievement Theory of McClelland (1965) holds that there would be relatively greater amount of entrepreneurship activities in societies where the need for achievement is relatively high. It emphasized that when the need for achievement is sufficiently stimulated in the society through education, there would be greater likelihood of them setting up their own businesses after graduation. This theory aligns well with the objective of entrepreneurship education in schools.

\section{Challenges of Entrepreneurship Education in Nigeria}

Despite the apparent shortsightedness in the nation's education curriculum which only saw the need for entrepreneurship education when the nation was already caught in the web of graduate unemployment, the implementation of the programme is itself fraught with a myriad of challenges. As noted by Okebukola, (2004) and Onyeachno (2008), poor curriculum implementation which has been a common phenomenon in the Nigerian education landscape, preventing the realization of the objectives of many specialized education programme, is a apparently the bane of entrepreneurship education among tertiary educational institutions in Nigeria.

The teaching of the course is made theoretically boring in which students are made to write business proposals in groups of ten or more. In many institutions the course is taught without visits to industries for students to see for themselves some practical industrial activities. Gabadeen and Raimi (2012) observed that there is also a virtual absence of talks from professional business gurus from the locality. In many institutions students have no access to 
relevant text books and other instructional materials for the course.

Inadequate funding appears to be at the core of the inadequacies surrounding the implementation of entrepreneurship education programme. This fact according to Gabadeen and Raimi (2012) has been attested to by the National Universities Commission (NUC), the National Board for Technical Education (NBTE) and the National Commission for Colleges of Education (NCCE). The above three bodies are the controllers and regulators of tertiary education in Nigeria. On the part of the students is the issue of wrong mindset in which some of them see the course as just another elective course to increase their academic work load. This negative mindset prevents the learners from showing interest in the course.

Outside the school environment, the Nigerian business environment does not appear inviting enough for young entrepreneurs. Securing business capital is an issue due to high interest rate and difficult collaterals by financial institutions. Government channels for funding small and medium enterprises (SMEs) are also fraught with corrupt practices. More daunting are equally the challenges of incorporation, inadequate infrastructure, high and multiple taxation and high cost of raw materials (Ariyo, 2005; Gabadeen and Raimi, 2012).

\section{Objectives of the Study}

Since the introduction of Entrepreneurship Education Programme into the curriculum of tertiary educational institutions in Nigeria in 2007, there has been a dearth of documentary evidence of studies conducted to find out the impact the programme is having on job creation for beneficiaries.

This study therefore aims at filling this gap by finding out:

(1) The extent to which this programme is implemented among tertiary educational institutions in Cross River State.

(2) The extent to which the programme has inculcated entrepreneurial spirit among beneficiaries.

(3) The extent to which Entrepreneurship Education has created self-employment among graduates.

(4) How the beneficiaries view the Entrepreneurship Education Programme.

\section{Research Questions}

The research is guided by the following questions:

(1) To what extent has Entrepreneurship Education programme been implemented among tertiary education institutions in Cross River State?

(2) To what extent has Entrepreneurship Education programme stimulated the spirit of entrepreneurship among beneficiaries?

(3) To what extent has Entrepreneurship Education programme created self-employment for beneficiaries? 
(4) What views do beneficiaries of Entrepreneurship Education Programme hold about the course?

\section{Research Procedure}

This study adopted ex-post facto research design. This is so because it is an evaluation of the extent of implemented of the ENT Education programme among the tertiary educational institutions in Cross River State for the past ten years (2007-2016). The researchers are only finding out the status quo concerning the implementation of the ENT Education programmes with a view of offering suggestions for improvement. If need be.

Cross River State is one of the 36 states in the Federal Republic of Nigeria. It is located on the south-south geo-political zone, one of the oil producing states of Nigeria. The state has four tertiary educational institution, viz, University of Calabar, Cross River University of Technology Calabar, Federal College of Education, Obudu and Cross River State College of Education, Akamkpa.

The population of the study comprise of all graduates from the four tertiary educational institution in Cross River State since the inception of the ENT Education programme (2007). Due to lack of accurate date on the number of graduates from these institutions on yearly basis, it is estimated that the total number of graduates from the four institutions covering the study period (2007-2016) is about 26,000 .

The researchers therefore decided to sample $10 \%$ of the population. Thus 2,600 graduates were earmarked as samples which were drawn from five major towns of the state, viz, Calabar, Ugep, Ikom, Ogoja and Obudu at 1000 for Calabar and 400 each for the rest of the towns, Calabar, being the state capital and the attraction of the elite population is allotted higher samples.

The instrument used for data collection was the researchers- made questionnaire titled "Entrepreneurship Education and Graduate Employment Questionnaire". It was a 11-item instrument meant to find out the extent of implementation of ENT education programme and the impact it has created on graduates employment.

Respondents were expected to tick "Yes" or "No" on the items provided. Data was collected using four research assistants in each of the four towns except Calabar where six assistants were used alongside the researchers. Most of the research assistants were teachers in primary and secondary schools. Collation of data showed that 2396 (92.15\%) research instruments were returned. Data was analyzed using simple percentages. A score of $50 \%$ and above was deemed high while anything below $50 \%$ was considered low. Each item on the instrument was analyzed separately. 
Table 1. Number and Percentage of Respondents.

\begin{tabular}{l|l|l|l|l|l|l}
\hline S/N & No of Respondents =2396 & Yes & No & Yes & No & Remarks \\
\hline 1. & I offered ENT while in school & 1624 & 772 & 67.78 & 32.22 & Positive \\
\hline 2. & The course was well taught and examined & 912 & 1484 & 38.06 & 61.94 & Negative \\
\hline 3. & There were good teachers for the course & 754 & 1642 & 31.47 & 68.53 & Negative \\
\hline 4. & Professional from outside also taught us & 556 & 1840 & 23.21 & 76.79 & Negative \\
\hline 5. & The course introduced me to many trades & 1420 & 976 & 59.27 & 40.73 & Positive \\
\hline 6. & Through the course I am self-employed & 238 & 2158 & 9.93 & 90.07 & Negative \\
\hline 7. & There were no good teachers for the course & 1732 & 664 & 72.29 & 27.71 & Negative \\
\hline 8. & No good textbooks for the course & 1822 & 574 & 76.04 & 23.96 & Negative \\
\hline 9. & We did not engage in practicals & 2030 & 366 & 84.72 & 15.28 & Negative \\
\hline 10. & ENT is a good course for self-employment & 2178 & 442 & 81.55 & 18.45 & positive \\
\hline 11. & $\begin{array}{l}\text { Through it I visited industries that made me } \\
\text { self-employed }\end{array}$ & 1954 & 442 & 81.55 & 18.45 & Negative \\
\hline
\end{tabular}

\section{Result Interpretation and Discussion of Findings}

From the analysis of the data as presented above the following deductions could be made about the implementation of Entrepreneurship Education among tertiary educational institutions in Cross River State.

(1) Entrepreneurship is widely offered by tertiary educational institutions in Cross River State with a positive response of $67.78 \%$.

(2) Majority of the graduates $(61.94 \%)$ are of the opinion that the course is not well taught by tertiary educational institution in the area under study.

(3) Graduates of the educational institutions hold a largely negative view (68.53\%) of the efficiency of course lecturers.

(4) Gurus and professionals of industries from outside the campuses were not engaged $(76.79 \%)$.

(5) A slightly above average (59.27\%) respondents admit that the course introduced them to many trades and skills.

(6) The Entrepreneurship Education programme has started making positive impact (9.93\%) on self-employment.

(7) A high percentage $(90.90 \%)$ of the respondents are of the view that the course has great potentials for self-employment for graduates but feel that the programme is not well implemented in schools.

\section{Discussion of Finding}

From the findings of this research, it could be deduced that entrepreneurship educational programme is widely implemented among tertiary educational institutional in Cross River State as shown by 67.78 positive response by graduates within the study period. This is not surprising became it is a directive from the Federal Republic of Nigeria for all tertiary 
educational institution on the country from 2007/2008 academic session (Gabadeen and Raimi, 2012).

The view by respondents that the course is not well implemented or taught appears to be a typical Nigerian characteristic in Curriculum and project implementation (Okebukda, 2004, and Onyeachu, 2008). This practice has prevented the objectives of many laudable educational programmes and projects from being realized.

The largely negative view of the efficiency of teachers of the programme is corroborated by the teachers themselves. An earlier research (yet be published) by these researchers showed that over $80 \%$ of teachers teaching Entrepreneurship Education have neither attended a workshop or conference on the course. More so the number of teachers teaching the course was found to be below the expected.

The result shows that the implementation of this education programme is localized within the schools and their teachers. Experts and professionals from industries around are not engaged in teaching the students. This limits the students perception of the course to be a purely school affair. This may be due to the inadequate funding of the programme for such experts to be used. NUC, NBTE and NCCE have attested to inadequate funding of the programme as in Gabadeen et al (2012). A high proportion of the respondents hold the view that the course has great potentials for self-employment and that through it they were introduced to many trades and skills. Also $9.93 \%$ of respondents agreed that through the knowledge and insight the gained from the educational programme, they are now self-employed.

The percentage of those who have become self-employed through the inspiration they derived from the course appears to be low (9.93\%). This may not be unconnected with the challenging nature of setting up a business in Nigeria which Ariyo (2005) has identified to include inadequate infrastructures, high and multiple taxation and high cost of raw materials.

\section{Conclusion}

From the findings of this study it can be concluded that Entrepreneurship Education programme has gained acceptance in most tertiary educational institutions in Nigeria. Graduates from tertiary educational institutions in Nigeria, equally hold a preponderant view that Entrepreneurship Education holds high prospects for self-employment of beneficiaries.

It can also be concluded that the programme lacks adequate implementation in the area of inadequate teachers in terms of number and training, the students not being adequately exposed to professionals and industries outside their school setting, the funding and logistics for practicals not adequately provided. It is a laudable educational programme that holds high prospects for mitigating of graduate unemployment in Nigeria if it is well-funded and implemented.

\section{Recommendations}

Based on the findings of this research, it could be recommended as follows: 
(1) As the bedrock of any educational programme, teachers of Entrepreneurship Educational programme should be increased in number to cope will the number of students, and adequately trained and deployed.

(2) Proprietors of tertiary educational institutions should provide adequate logistics and funding for the Entrepreneurship Education units to effectively carry out their mandate.

(3) The teaching of Entrepreneurship Education should combine theory with practicals to leave a lasting effects on the learners. It should also involve visitation to some industries within the locality and use of professionals from those industries.

(4) Federal and state governments in Nigeria should ensure that infrastructural facilities like road and electricity are improved upon for the ease of doing business and wellbeing of citizens.

(5) The process of business incorporation and access to funding should be made less rigorous, especially for small and medium Entrepreneurs (SMEs) by government to create attraction for and survival of SMEs.

\section{References}

ACS, Z. J., \& Stoney, D. J. (2004). Introduction: Entrepreneurship and Economic Development, Regional Studies 38/8.

Adegun, M. (2003). Economics of Education, Lagos, Olatunji Press.

Ariyo, D. (2005). Small Firms are the Backbone of the Nigerian Economy, http:/www africaeconomicanalysis org.

Fafunwa, A. B. (1995). History of Education in Nigeria. Ibadan, NPS. Educational Publishers.

Fajana, S. (2000). Functioning of the Nigerian Labour Market, Lagos Labofin and Co.

Federal Republic of Nigeria (2008). National Policy on Education, Yaba-Lagos, NERDC Press.

Gabadeen, W. O., \& Raimi, L. (2012). Management of Entrepreneurship Education in Nigerian Higher Institutions, Issues, Challenges and way forward; Abuja International Journal of Education and Management Sciences (ABIJEMS) 2/1-26.

Kanothi, R. N. (2009). The Dynamics of Entrepreneurship in ICT: A case of mobile phone downstream services in Kenya; working paper No. 466, The Netherlands, Institute of social sciences.

McClelland, D. C. (1965). Achievement and Entrepreneurship, Journal of personality and social psychology, 4 (389-392).

Miniti, M., \& Levesque, M. (2008), Recent Developments in the Economics of Entrepreneurship, Journal of Business Venturing, 23 (603-612). 


\section{Macrothink \\ International Journal of Human Resource Studies \\ ISSN 2162-3058 2018, Vol. 8, No. 3}

https://doi.org/10.1016/j.jbusvent.2008.01.001

Naude, W. (2007). Peace, prosperity and pro-growth Entrepreneurship, Helsinki, United Nations University.

Okebukola, P. A. O. (2004), Curriculum Implementation in Nigeria $21^{\text {st }}$ cent, in Noah, AOK, Shonibare, D, OJo, A. A., \& Olujuwon T. (Eds), curriculum Implementation and Professionalizing Teaching in Nigeria, Lagos, Central Educational services.

Olaniyan, D. A., \& Okemakinde, T. (2008). Human Capital Theory; Implications for Educational Development, European Journal of Scientific Research, 24/2 (157-162).

Onyeachu, J. A. E. (2008). Curriculum Implementation at the Primary Education Level, challenges of the $21^{\text {st }}$ century. In Journal of Research and Development 10/1

Raimi, L., Shokunbi, M. O., \& Peluola, S. B. (2010). Entrepreneurship and Development Institutions in Nigeria: prospects and challenges in perspective of Entrepreneurship and Economic Development in Nig. Edited by Subair, K, Kwarra, Oladipo Publishers.

Robert, B. (1991). Economic Growth in a Cross Section of Countries, Quarterly Journal of Economics, 106/2

Udo, E. A. (1983). Who are the Ibibio? Onitsha, African Fep publishers Ltd.

Van-Den-Berg, H. (2001). Economic Growth and Development, New York, McGraw-Hill.

Yahaya, U. (2011). Why we set up Entrepreneurship studies in varsities - F.G, available on http/wwwtehnigerianvoice.com/nvnes/45849/1, june16, 2012.

\section{Copyright Disclaimer}

Copyright for this article is retained by the author(s), with first publication rights granted to the journal.

This is an open-access article distributed under the terms and conditions of the Creative Commons Attribution license (http://creativecommons.org/licenses/by/4.0/). 